\section{Ks. Mirosław S. Wróbel}

Katolicki Uniwersytet Lubelski Jana Pawła II e-mail: miwrobel@kul.pl

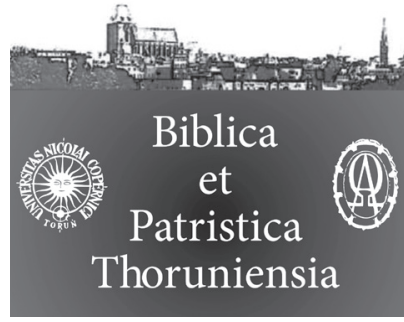

8 (2015) 1 ISSN 1689-5150

\title{
"To wam przykazuję, abyście się wzajemnie miłowali" (J 15,17). Wzajemna miłości uczniów Jezusa jako budowanie wspólnoty Kościoła w świetle czwartej Ewangelii
}

\author{
"This I command you, that you love one another" \\ (Jn 15:17). The reciprocal love of the disciples \\ of Jesus as the formation of the Church \\ community according to the Fourth Gospel
}

Streszczenie. W niniejszym artykule autor stara się odpowiedzieć na następujące pytania: Jaka jest funkcja i znaczenie przykazania miłości w czwartej Ewangelii? Jak ukazana jest relacja miłości pomiędzy Ojcem i Synem? W jaki sposób Jezus manifestuje swoją miłość wobec uczniów? W jaki sposób uczniowie poprzez realizację przykazania miłości stają się budowniczymi Domu, któremu na imię Kościół? Poszukiwanie odpowiedzi na te pytania zostanie przedstawione w czterech aspektach: 1. Miłość Ojca objawiona w Synu; 2. Miłość Jezusa wobec uczniów; 3. Przykazanie miłości w życiu uczniów; 4. Budowanie wspólnoty Kościoła w przestrzeni miłości.

\begin{abstract}
In the present article the author searches for the answers on the following questions: What is the function and meaning of the commandment of love in the Fourth Gospel? How is the relation of love between Father and Son? How Jesus manifests His love to the disciples? How the disciples of Jesus form the Church community by realization of the commandment of love? The answers on these questions are searched in the following aspects: 1 . The love of Father revealed in His Son; 2. The love of Jesus to His disciples; 3 . The commandment of love in the life of the disciples; 4 . The formation of the Church community in the space of love.
\end{abstract}

Słowa klucze: Przykazanie miłości; wspólnota uczniów; Ewangelia Janowa.

Keywords: The commandment of love; the community of the disciples; the Gospel of John. 
$\mathrm{N}$ a kartach czwartej Ewangelii podkreślany jest horyzontalny wymiar miłości w życiu wspólnoty ${ }^{1}$. Wyrazem tego jest pięciokrotne wezwanie Jezusa do wzajemnej miłości we wspólnocie Jego uczniów ${ }^{2}$. Wszystkie te wezwania zawarte są w kontekście większego bloku tekstowego opisującego nauczanie Jezusa podczas Ostatniej Wieczerzy (J 13-17), który pod względem gatunku literackiego jest identyfikowany jako „Mowy pożegnalne” („Mowy testamentalne”, „Mowy pocieszenia”). W odróżnieniu od wcześniejszej części Ewangelii („Księga Znaków” - rozdziały 1-12) „Mowy pożegnalne” nie mieszczą się w ramach publicznej działalności Jezusa, lecz są skierowane bezpośrednio do Jego uczniów ${ }^{3}$. Jezus zwraca się do uczniów, aby im wyjaśnić sens swego życia oraz przygotować ich do rozstania i do ostatecznego zwycięstwa. W swoim testamencie do uczniów Jezus podkreśla szczególną wage przykazaniu miłości (J 13,31-35; 15,12-17). Jego realizacja ma budować komunię członków Kościoła, która czerpie swe siły witalne z relacji miłości pomiędzy Ojcem, Synem i Duchem Świętym.

W niniejszym artykule poszukujemy odpowiedzi na następujące pytania: Co Jezus Janowy rozumie pod pojęciem „miłość”? Jak ukazana jest relacja miłości pomiędzy Ojcem i Synem? W jaki sposób Jezus ukazuje swoją miłość wobec uczniów? Jak konkretnie powinna wyglądać postawa miłości uczniów? W jaki sposób uczniowie poprzez realizację przykazania miłości stają się budowniczymi Domu, któremu na imię Kościół? Poszukiwanie odpowiedzi na te pytania zostanie przedstawione w czterech punktach: 1. Miłość Ojca objawiona w Synu; 2. Miłość Jezusa wobec uczniów; 3. Przykazanie miłości w życiu uczniów; 4. Budowanie wspólnoty Kościoła w przestrzeni miłości

\section{Miłość Ojca objawiona w Synu}

Czwarta Ewangelia przedstawia Jezusa jako Bożego Posłańca objawiającego kochające oblicze Ojca ${ }^{4}$. W Jezusie - Wcielonym Słowie każdy wierzący otrzymuje łaskę spotkania z Tym, który jest Niewidzialny, Transcendentny i Wieczny. Papież Benedykt XVI w adhortacji apostolskiej Verbum Domini podkreśla, że „Słowo, które od początku jest u Boga i jest Bogiem, objawia nam samego Boga w dialogu miłości między Osobami Boskimi i zaprasza nas do uczestnictwa

1 Zob. L. Cerfaux, La charité fraternelle, s. 27-40; B. Maggioni, Amatevi come io vi ho amato, s. 158-167; T. Hermann, Miłość braterska, s. 133-139.

2 J 13,34- 2 razy; J 13,35; J 15,12; $15,17$.

3 N. Farelly, The Disciples in the Fourth Gospel, s. 63-66.

4 Zob. M.S. Wróbel, Jezus Janowy jako Objawiciel oblicza Ojca, s. 191-203. 
w nim"5. Motywem harmonii działania pomiędzy Ojcem i Synem jest miłość ( J 3,35 „Ojciec miłuje Syna i wszystko oddał w Jego ręce”; J 5,20 „Ojciec bowiem miłuje Syna i ukazuje Mu to wszystko, co On sam czyni”). W ten sposób Jezus dokonuje czynów w imię Ojca i wszyscy wierzący mogą rozpoznać w Jego działaniu zamysły samego Boga (J 4,34 „Moim pokarmem jest wypełnić wolę Tego, który Mnie posłał, i wykonać Jego dzieło”; J 8,29 „A Ten, który Mnie posłał, jest ze Mną; nie pozostawił Mnie samego, bo Ja zawsze czynię to, co się Jemu podoba").

Na szczególną więź odwiecznej miłości pomiędzy Ojcem i Synem wskazuje

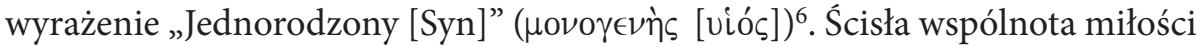
odwiecznego Logosu i Ojca zostaje obrazowo przedstawiona jako przebywanie Syna w łonie $\mathrm{Ojca}^{7}$ (J 1,18 - „Boga nikt nigdy nie widział, Ten Jednorodzony Bóg, który jest w łonie Ojca, o Nim pouczył”). Zbawcza moc Jezusa jest skutkiem ścisłej wspólnoty miłości Ojca z Synem i wiąże się z całkowitym wypełnieniem przez Syna woli Posyłającego Ojca ${ }^{8}$. Syn zawsze pozostaje w komunii ze swoim Ojcem (J 8,16 „A jeśli nawet będę sądził, to sąd mój jest prawdziwy, ponieważ Ja nie jestem sam, lecz Ja i Ten, który Mnie posłał”; J 16,32 - „Oto nadchodzi godzina, a nawet już nadeszła, że się rozproszycie - każdy w swoją stronę, a Mnie zostawicie samego. Ale Ja nie jestem sam, bo Ojciec jest ze Mną"). Więź pomiędzy Jezusem a posyłającym Go Ojcem jest tak ścisła, że w Synu można zobaczyć Ojca (J 8,19 „Na to powiedzieli Mu: 'Gdzie jest Twój Ojciec?' Jezus odpowiedział: 'Nie znacie ani Mnie, ani Ojca mego. Gdybyście Mnie poznali, poznalibyście i Ojca mego”; J 12,45 „A kto Mnie widzi, widzi Tego, który Mnie posłał”; J 14,9 „Odpowiedział mu Jezus: Filipie, tak długo jestem $\mathrm{z}$ wami, a jeszcze Mnie nie poznałeś? Kto Mnie zobaczył, zobaczył także i Ojca. Dlaczego więc mówisz: 'Pokaż nam Ojca?'”). Czwarta Ewangelia podkreśla wzajemne zamieszkanie Ojca w Synu i Syna w Ojcu (J 10,30.38 „Ja i Ojciec jedno jesteśmy... Ojciec jest we Mnie, a Ja w Ojcu”) ${ }^{9}$. W obrazie tym wyraźnie widać głęboką wspólnotę miłości i jedności pomiędzy Ojcem i Synem. Wspólnota ta nie niszczy jednak różności pomiędzy Ojcem i Synem. W relacji tej tożsamość Boga jako Ojca realizuje się ze względu na Syna, natomiast tożsamość Jezusa jako Syna realizuje się ze względu na Ojca. Wspólnota miłości pomiędzy Ojcem i Synem realizuje się poprzez wzajemne poznanie (J 10,15a „Podobnie jak Mnie zna Ojciec, a Ja znam Ojca”). Poznanie w myśli semickiej nie ogra-

\footnotetext{
5 Benedykt XVI, Adhortacja apostolska Verbum Domini, nr 6.

6 J 1,14.18; 3,16.18.

7 Zob. L. Devillers, Le sein du Père, s. 63-79.

$8 \mathrm{~J} 4,34 ; 5,30 ; 6,38.39 .40$.

9 Zob. M.S. Wróbel, 'Ja i Ojciec jedno jesteśmy’ (J 10,30), s. 53-62.
} 
nicza się tylko do sfery intelektualnej, ale dotyczy też doznania, doświadczenia przedmiotu, który się poznaje. Poznanie to ma charakter dynamiczny wyrażający się przyjęciem objawienia i życiem zgodnym z przyjętym objawieniem. Poznanie zawiera w sobie realizację głębokiej komunii opartej na miłości i jedności.

\section{Miłość Jezusa wobec uczniów}

Ewangelia Janowa mocno podkreśla postawę miłości Jezusa wobec swoich uczniów. Miłość ta przejawia się jako wspierająca i pomagająca w licznych cudach Jezusa: na weselu w Kanie (J 2,1-11), przy uzdrowieniu chromego (J 5,1-11), w cudownym rozmnożeniu chleba (J 6,5-16), w uzdrowieniu niewidomego od urodzenia (J 9,1-38), we wskrzeszeniu Łazarza (J 11,1-44). Miłość Jezusa na kartach czwartej Ewangelii jawi się jako miłość „aż do końca”, „aż po krzyż" (J 13,1 „Jezus wiedząc, że nadeszła Jego godzina przejścia z tego świata do Ojca, umiłowawszy swoich na świecie, do końca ich umiłował”). Źródłem tej miłości jest Ojciec, który obdarowuje nią swego Syna. Dar ten zostaje przez Syna przyjęty i zrealizowany przez Niego jako dar miłości dla ludzkości. Dar Boga Ojca wobec Jezusa znajduje swą kontynuację w darze wobec ludzi. Szczytem tego daru Ojca dla ludzi jest Jego własny Syn. W darze Syna następuje objawienie najwyższej miłości Ojca. Dar Ojca jest realizowany w osobie Jezusa, który otrzymuje wszystko od Ojca przekazując ten dar ludziom. Jedność obydwu darów została objawiona w arcykapłańskiej modlitwie Jezusa (J 17,7-8.22 „Teraz poznali, że wszystko, cokolwiek Mi dałeś, pochodzi od Ciebie. Słowa bowiem, które Mi powierzyłeś, im przekazałem, a oni je przyjęli i prawdziwie poznali, że od Ciebie wyszedłem, oraz uwierzyli, żeś Ty Mnie posłał... I także chwałę, którą Mi dałeś, przekazałem im, aby stanowili jedno, tak jak My jedno stanowimy" ${ }^{10}$. U początku każdego daru jest miłość. Bóg dał wszystko Synowi, gdyż Go miłuje. Jednorodzonego Syna uosabia miłość skierowana do całej ludzkości (J 3,16 „Tak bowiem Bóg umiłował świat, że Syna swego Jednorodzonego dał, aby każdy, kto w Niego wierzy, nie zginął, ale miał życie wieczne").

Św. Jan uwypukla tematykę miłości Syna wobec swoich uczniów poprzez zastosowanie symbolicznego terminu „godzina” (gr. ఝр $\alpha$ ). Rzeczownik ten występuje w czwartej Ewangelii 25 razy w liczbie pojedynczej i 1 raz w liczbie mnogiej. (J 11,9). Poprzez użycie tego terminu Ewangelista stwarza w swojej narracji pewne napięcie, które polega na oczekiwaniu momentu nadejścia ja-

10 Zob. E. Käsemann, Jesu letzter Wille nach Johannes 17; F. Gryglewicz, Modlitwa Arcykapłańska, s. 113-146; M.S. Wróbel, 'Ojcze... Uwielbij swego Syna, aby Syn uwielbił Ciebie...' (J 17,1), s. 101-117. 
kiegoś ważnego wydarzenia. Typowe napięcie występuje w J 7,30 i J 8,20, kiedy to "Żydzi” próbują pojmać Jezusa, ale nie mogą tego uczynić, ponieważ nie nadeszła jeszcze Jego „godzina”. Nadejście „godziny” niezależne od woli nieprzyjaciół Jezusa - wskazuje także na fakt rozpoczęcia Paschy - przejścia Jezusa z ziemi do Ojca w Niebie (J 13,1 „Jezus wiedząc, że nadeszła Jego godzina przejścia $z$ tego świata do Ojca”). W tekście wyraźnie jest mowa o tym, że termin ten łączy się ze skazaniem Jezusa na śmierć. Jest to więc "godzina" związana z Paschą, „godzina” śmierci. W związku z tym Jezus jakby wzbrania się przed tą właśnie "godziną”. W J 13,1 kondensuje się cała teologia nadejścia "godziny” (Pascha, zejście z tego świata, zmartwychwstanie, „godzina” miłości do Ojca i miłości do ludzi). W J 19,14 ewangelista konkretyzuje ową "godzinę" z godziną szóstą. Jest to czas ofiarowania baranka paschalnego. Śmierć Jezusa inauguruje nową Paschę. Nadejście godziny w Ewangelii św. Jana łączy się więc ze świętem Paschy, z męką i uwielbieniem Syna Człowieczego. Realizuje się tu Boży plan zbawienia. Jest to również godzina miłości aż do końca. W godzinie tej można dostrzec „krzyż”, który nie kończy się na męczeństwie, lecz prowadzi do chwalebnego zwycięstwa (J 12,23). Krzyż jawi się jako znak Miłości Boga do ludzkości. Ewangelista ściśle łączy misterium paschalne z Miłością aż do końca. Chwalebna śmierć Jezusa objawia miłość Syna wobec człowieka. W Jezusowym wołaniu na krzyżu „wykonało się” wyraża się dokonanie największego dzieła miłości w tajemnicy pojednania Boga i człowieka. W ten sposób ziemia w „godzinie" Jezusa dotyka pocałunkiem miłości szczytów Nieba.

\section{Przykazanie miłości w życiu uczniów}

Przykazanie miłości braterskiej Jezus nazywa „nowym przykazaniem”, które

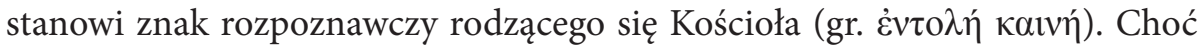
przykazanie miłości bliźniego istniało w Starym Testamencie (Kpł 19,18), to jednak przykazanie Jezusa jawi się jako nowe ze względu na nadaną mu przez Niego doskonałość. Chrystus w przykazaniu wzajemnej miłości podkreśla nowy przedmiot i nową przyczynę miłowania (J 13,34-35 „Przykazanie nowe daję wam, abyście się wzajemnie miłowali tak, jak Ja was umiłowałem; żebyście i wy tak się miłowali wzajemnie. Po tym wszyscy poznają, żeście uczniami moimi, jeśli będziecie się wzajemnie miłowali”). Prawdziwą nowością nie są tu idee, lecz sama osoba Jezusa uosabiająca miłość poprzez krzyż ${ }^{11}$. Jako „przykazanie Jezusa” (J 13,34; 15,12.17) staje się ono we wspólnocie uczniów regułą życia inspirowaną przykładem osoby Jezusa. Prawdziwa miłość braterska może

11 Benedykt XVI, Deus caritas est, nr 12. 
realizować się tylko wtedy, kiedy czerpie swój wzór i moc z miłości Jezusowej („Abyście się wzajemnie miłowali tak, jak Ja was umiłowałem”). Nie jest to miłość oparta na emocjach, lecz na autentycznym ofiarowaniu siebie w służbie Bogu i bliźniemu. Uczniowie miłując się wzajemnie powinni nieustannie swoje czyny zespalać z czynami Jezusa. Dzięki wzajemnej miłości mogą oni trwać w życiu ofiarowanym przez Jezusa, które przezwycięża śmierć. Zwycięstwo miłości nad śmiercią realizuje się w konkretnym wyzbywaniu się siebie i obumieraniu dla swojego „ja”. Im bardziej człowiek potrafi umrzeć dla siebie, tym bardziej może żyć dla innych. Rzeczywistość tę w sposób sugestywny i obrazowy wyraża tekst J 12,42 „Jeżeli ziarno pszenicy wpadłszy w ziemię nie obumrze, zostanie tylko samo, ale jeżeli obumrze, przynosi plon obfity". Ukrzyżowany Chrystus staje się wzorem i mocą dla wszystkich swoich uczniów, którzy w miłości ofiarują swe życie dla innych ${ }^{12}$. Wyraźnym rysem miłości wobec bliźniego jest jej służebny charakter. Jezus, który obmywa nogi swoim uczniom, łączy ten gest miłości ze słowem zachęty do naśladowania - J 13,15 „Dałem wam bowiem przykład, abyście i wy tak czynili, jak Ja wam uczyniłem”. Postawa Jezusa jest postawą proegzystencji - życia w służbie dla innych i taka powinna być postawa uczniów realizujących konkretnie wezwanie do wzajemnej miłości.

Życie uczniów we wzajemnej miłości stanowi według św. Jana drogę prowadzącą do domu Ojca (J 14,2-3; 17,24). Nauka Jezusa o przykazaniu wzajemnej miłości uczniów (J 15,12-17) zostaje usytuowana w kontekście alegorii o winnym krzewie (J 15,1-11). W alegorii tej Jezus jest krzewem winnym, Ojciec jest Ogrodnikiem a uczniowie Jezusa latoroślami. Tworzenie dynamicznej i głębokiej wspólnoty z Ojcem i Synem decyduje o owocnej egzystencji uczniów Jezusa: J 15,8 „Ojciec mój przez to dozna chwały, że owoc obfity przyniesiecie i staniecie się moimi uczniami”. W takiej wspólnocie realizuje się bowiem prawdziwa miłość. Dzięki miłości uczniowie są zjednoczeni ze sobą i doznają radości: J 15,11 „To wam powiedziałem, aby radość moja w was była i aby radość wasza była pełna”. Uczniowie Jezusa odgrywają ważną rolę, gdyż ich życie we wzajemnej miłości jest przedłużeniem misji samego Mistrza: J 20,21b „Jak Ojciec Mnie posłał, tak i Ja was posyłam”. Przyjęcie z wiarą przez uczniów objawienia Jezusa o Ojcu i jego realizacja w przestrzeni miłości czyni z nich przyjaciół Ojca i Syna ${ }^{13}$ : J 15,15 „Już was nie nazywam sługami, bo sługa nie wie, co czyni pan jego, ale nazwałem was przyjaciółmi, albowiem oznajmiłem wam wszystko, co usłyszałem od Ojca mego". Na istotną rolę misji uczniów wskazuje modlitwa arcykapłańska Jezusa, w której Jezus wstawia się u Ojca za

12 N. Farelly, The Disciples in the Fourth Gospel, s. 78-83.

13 Tytuł „przyjaciel Boga” na kartach biblijnych pojawia się w odniesieniu do Abrahama (Iz 41,8; Jk 2,23) oraz Mojżesza (Wj 33,11). 
swoimi uczniami. Swoją modlitwą Jezus obejmuje wszystkie generacje uczniów pozostających we wspólnocie miłości: J 17,9 „Ja za nimi proszę, nie proszę za światem, ale za tymi, których Mi dałeś, ponieważ są Twoimi”; J 17,20 „Nie tylko za nimi proszę, ale i za tymi, którzy dzięki ich słowu będą wierzyć we Mnie”.

\section{Budowanie wspólnoty Kościoła w przestrzeni miłości}

Jezus wypełniający w miłości aż do końca wolę swojego Ojca, choć umiera na krzyżu, to jednak jako Zmartwychwstały Pan obecny jest we wspólnocie Kościoła w sakramentach świętych, które wprowadzają Jego wyznawców w przestrzeń miłości ${ }^{14}$. Wspólnota uczniów w Ewangelii Janowej idąca drogą do domu Ojca nie jest jakąś anonimową grupą ludzi, lecz jest utworzona z konkretnych osób: uczniów powołanych przez Jezusa (J 1,35-51), Samarytanki (4:1-26), urzędnika królewskiego (J 4,46-54), niewidomego od urodzenia (9:1-41). Wielu z nich jest wymienionych po imieniu: Andrzej, Szymon Piotr, Filip, Natanael, Tomasz, Marta, Maria, Łazarz. Spotkanie tych ludzi z Jezusem wzbudza w nich wiarę, która prowadzi ich do głębszego poznania wspólnoty miłości z Ojcem, Synem i Duchem Świętym oraz do owocniejszego realizowania zadania wzajemnej miłości ${ }^{15}$. Wspólnota wiernych uczniów Jezusa zostaje mocno skontrastowana z tymi, którzy nie uwierzyli i którzy utożsamieni zostają ze światem wrogo nastawionym do Jezusa i Jego naśladowców ${ }^{16}$. Odrzucają oni prawdziwego Ojca poddając się pod wpływ diabła, który zostaje nazwany ich ojcem $(J 8,44)^{17}$. Miłość zamieniają oni w nienawiść stając się przeciwnikami Boga i jego naśladowców.

Wzajemna miłość uczniów tworzących wspólnotę pozwala przeciwstawiać się nienawiści i prześladowaniom ze strony przeciwników Kościoła. Miłość braterska staje się znakiem obecności Boga w życiu Kościoła. W wiernym trwaniu uczniów Jezusa w przestrzeni miłości dopomaga Duch Święty. Wspólnota Janowa otrzymuje obietnice Parakleta, który ma dopomóc w pogłębieniu wiary i w pełnej realizować przykazania miłość. Paraklet nie tylko przebywa w wie-

14 L. Zani, Le mani del risorto.

15 Rekonstrukcja historii wspólnoty Janowej jest przedmiotem badań współczesnych uczonych. $\mathrm{Z}$ ważniejszych prac na ten temat zob. J. L. Martyn, History and Theology; Idem, Glimpses into the History, s. 149-179; R. E. Brown, The Community of the Beloved Disciple; M. Hengel, The Johannine Question; K. Wengst, Bedrängte Gemeinde; C. G. Lingad, The Problems of Jewish Christians.

$16 \mathrm{~J} 15,18-16,4 ; 17,14-16$.

17 Zob. M.S. Wróbel, Who are the father and his children in Jn 8:44?. 
rzących (J 14,17), doprowadza ich do całej prawdy (J 16,13), otacza chwałą Chrystusa (J 16,14), lecz także jest tym, który przychodzi, aby przekonać świat o grzechu, sprawiedliwości i sądzie. Jawi się On jako dar dla wspólnoty, zapewniający jej więź z Bogiem i umacniający we wzajemnej miłości w konfrontacji z judaizmem ${ }^{18}$. We wspólnocie wiary, jedności i miłości z Ojcem, Synem i Duchem Świętym wierni uczniowie mogą czynić dzieła na miarę swego Mistrza (J 14,12). Paraklet pomaga uczniom w sercu interioryzować naukę Jezusa i sprawia głębię zrozumienia. Celem działania Parakleta jest pouczanie, aby prawdy przekazane przez Jezusa trwały w uczniach i były głęboko przyjęte w sercu (działanie pneumatyczne). Uczniowie realizujący przykazanie miłości we wspólnocie Kościoła otrzymują obietnicę, że Paraklet - Duch Prawdy - Duch Święty będzie z nimi na zawsze (J 14,17). Wyrażenie "być z" jest formułą wziętą ze Starego Testamentu wyrażającą szczególną pomoc Boga udzielaną tym, którym powierza on posłannictwo ${ }^{19}$. Formuła ta użyta w odniesieniu do Parakleta oznacza, że przyjmie On obecność, asystencję Jezusa wśród uczniów. Obecność Parakleta będzie analogiczna do obecności Jezusa wśród nich. Dar Parakleta oznacza skuteczne przedłużenie tego, czym Jezus był dla uczniów w czasie życia ziemskiego. Bardzo wymowna w tym kontekście jest scena, gdy Jezus po swym zmartwychwstaniu przekazuje uczniom Ducha Świętego, aby kontynuowali Jego dzieło na ziemi: J 20,22 „Po tych słowach tchnął na nich i powiedział im: «Weźmijcie Ducha Świętego!”.

Wzajemna miłość członków Kościoła buduje jedność we wspólnocie. Podobnie jak nie doznała podziału tunika Jezusa (J 19,23n) i sieć Piotra (J 21,11), tak również wspólnota Kościoła nie powinna ulegać podziałom ${ }^{20}$. Owce pochodzące $\mathrm{z}$ różnych owczarni powinny stanowić jedno pod przewodnictwem jednego Pasterza: J 10,16 „... i nastanie jedna owczarnia, jeden pasterz”. O jedność członków Kościoła modli się sam Jezus: J 17,21-23 „Aby wszyscy stanowili jedno, jak Ty, Ojcze, we Mnie, a Ja w Tobie, aby i oni stanowili w Nas jedno... Oby się tak zespolili w jedno, aby świat poznał, żeś Ty Mnie posłał i żeś Ty ich umiłował tak, jak Mnie umiłowałeś”. Jedność wzajemnie miłujących się uczniów jest dla świata najbardziej wyrazistym świadectwem działania Boga we wspólnocie Kościoła.

Podsumowując możemy stwierdzić, że tematyka miłości w czwartej Ewangelii jest kluczowym motywem teologii św. Jana. Miłość jawi się jako dynamiczna rzeczywistość, która ma swoje źródło w Ojcu a ukonkretnia się w działaniu

\footnotetext{
18 J 14,15-17.25-26; 15,26-27; 16,4b-11.12-15.

19 Rdz 28,15; Wj 3,12; Jer 1,8.

20 Zob. F. Gryglewicz, Dwie Janowe metafory o Kościele, s. 135-139; A. Paciorek, Ewangelia umiłowanego ucznia, s. 250-251.
} 
Jezusa i Jego uczniów. Miłość jako przykazanie nowe (J 13,34) i przykazanie Jezusa (J 15,12.17) staje się najważniejszym zadaniem uczniów chcących kontynuować na ziemi misję swojego Mistrza. W odróżnieniu od synoptyków i listów św. Pawła, Ewangelia św. Jana nie mówi o miłości bliźniego, lecz o miłości względem brata (miłość braterska) lub wzajemnej miłości w obrębie określonej społeczności. Ewangelista Jan nie uwypukla - tak jak synoptycy miłości wobec wszystkich ludzi, nawet wobec nieprzyjaciół (Mt 5,43-48), lecz zwraca szczególną uwagę na miłość łączącą członków nowego ludu Bożego. Nie ogranicza to uniwersalnego wymiaru miłości w czwartej Ewangelii, gdyż wzorem prawdziwej miłości dla uczniów jest miłość Chrystusa, która obejmuje wszystkich ludzi (J 12,32 „A Ja, gdy zostanę nad ziemię wywyższony, przyciągnę wszystkich do siebie"). Nauczyciel z Nazaretu nie ogranicza się tylko do słownych deklaracji na temat miłości braterskiej, lecz sam staje się jej najdoskonalszym wzorem. Św. Jan poucza, że miłość Jezusa do uczniów jest podstawą i normą miłości braterskiej (J 13,34; 15,12). To Jezusowe „umiłowanie do końca” znajduje swoją konkretyzację w ustanowieniu Eucharystii oraz w męce, śmierci i zmartwychwstaniu. Jezus przez swoją ofiarą ukazuje szczyty prawdziwej miłości: „Nikt nie ma większej miłości od tej, gdy ktoś życie swoje oddaje za przyjaciół swoich" (J 15,13). W świetle Jego Krzyża wyraźnie widać, że miłość jest całkowitym, bezinteresownym darem dla innych. W rozumieniu czwartej Ewangelii miłość to nie abstrakcyjna formuła i mało znaczące słowo, lecz postawa ofiarowania i służby wobec Boga i braci. W przestrzeni takiej miłości człowiek może doświadczać prawdziwej wolności oraz zwycięstwa nad grzechem i śmiercią. Miłość braterska i jedność buduje dom, któremu na imię Kościół stając się znakiem wyróżniającym jego członków oraz zapewniając mu nieustanny rozwój. W przestrzeni miłości Kościół staje się Domem dla wszystkich, którzy w prawdzie i wolności pragną zamieszkać w jego wnętrzu.

\section{Bibliografia}

Brown R.E., The Community of the Beloved Disciple. The Life, Loves, and Hates of an Individual Church in New Testament Times, New York 1979.

Cerfaux L., La charité fraternelle et le retour du Christ (Jo 13,33-38), w: Recueil, L. Cerfaux (ed.), Gembloux 1954, s. 27-40.

Devillers L., Le sein du Père: la finale du prologue du Jean, Revue biblique 112 (2005), s. $63-79$.

Farelly N., The Disciples in the Fourth Gospel. A Narrative Analysis of their Faith and Understanding, Tübingen 2010.

Gryglewicz F., Dwie Janowe metafory o Kościele, w: Kościół w świetle Biblii, J. Szlaga (red.), Lublin 1984, s. 135-139. 
Gryglewicz F., Modlitwa Arcykapłańska, w: Egzegeza Ewangelii św. Jana, Lublin 1992, s. 113-146.

Hengel M., The Johannine Question, London-Philadelphia 1989.

Hermann T., Miłość braterska według Ewangelii św. Jana, w: Egzegeza Ewangelii św. Jana, F. Gryglewicz (red.), Lublin 1992, s. 133-139.

Käsemann E., Jesu letzter Wille nach Johannes 17, Tübingen 1971.

Lingad, C.G., The Problems of Jewish Christians in the Johannine Community, Roma 2001.

Maggioni B., Amatevi come io vi ho amato, Parola Spirito e Vita 11 (1985), s. 158-167.

Martyn J.L., History and Theology in the Fourth Gospel, New York 1968.

Martyn J.L., Glimpses into the History of the Johannine Community, w: Lévangile de Jean. Sources, redaction, théologie, M. de Jonge (ed.), Leuven 1977, s. 149-179.

Paciorek A., Ewangelia umiłowanego ucznia, Lublin, 2000, s. 250-251.

Wengst K., Bedrängte Gemeinde und verherrlichter Christus. Der historische Ort des Johannesevangeliums als Schlüssel zu seiner Interpretation, Neukirchen-Vluyn 1981.

Wróbel M.S., 'Ojcze... Uwielbij swego Syna, aby Syn uwielbił Ciebie...' (J 17,1). Początek modlitwy Jezusa jako otwieranie ziemi Niebu (J 17,1-5), w: Modlitwa uwielbienia. Homo Orans, J. Misiurek - J.M. Popławski - K. Burski (red.), Lublin 2004, s. 101-117.

Wróbel M.S., Who are the father and his children in Jn 8:44? The literary, historical and theological analysis of Jn 8:44 and its context, Paris 2005.

Wróbel M.S., 'Ja i Ojciec jedno jesteśmy' (J 10,30). Chrystologia Ewangelii św. Jana wobec żydowskiego monoteizmu, w: Jezus jako Syn Boży w Nowym Testamencie $i$ we wczesnej literaturze chrześcijańskiej, Analecta Biblica Lublinensia 1, H. Drawnel (red.), Lublin 2007, s. 53-62.

Wróbel M.S., Jezus Janowy jako Objawiciel oblicza Ojca, Verbum Vitae 20 (2011), s. $191-203$.

Zani L., Le mani del risorto. Lesperienza pasquale dei discepoli nel Vangelo secondo Giovanni, Milano 2008. 